\title{
Seasonal evapotranspiration signatures under a changing landscape and ecosystem management in Nigeria: Implications for agriculture and food security
}

\author{
${ }^{*}$ Chineke T C, ${ }^{2}$ Idinoba M E and ${ }^{3}$ Ajayi O C
}

${ }^{*}$ Atmospheric Physics Group, Department of Physics, Imo State University, PMB 2000

Owerri, Nigeria. Email: chidiezie@yahoo.com

${ }^{2}$ Centre for International Forestry Research, Ouagadougou, Burkina Faso

${ }^{3}$ World Agroforestry Centre, P.O. Box 30798, Lilongwe 03, Malawi

\begin{abstract}
An understanding of the evapotranspiration processes and knowledge about the spatial and temporal rates of evapotranspiration is paramount for designing appropriate responses to climate change. But the knowledge about the processes is limited in many African countries. In this paper, we analyzed seasonal and regional trends of evapotranspiration for 36 state capitals of Nigeria and the federal capital, Abuja using data obtained from the International Water Management Institute (IWMI) for the period 1961-1990. Results show that the monthly mean evapotranspiration ranged from $2.68 \mathrm{~mm}$ in the month of August at Port-Harcourt $\left(7.00{ }^{\circ} \mathrm{E}\right.$ and $\left.4.75^{\circ} \mathrm{N}\right)$ in the coastal part of the country to $9.08 \mathrm{~mm}$ for the month of March at Sokoto $\left(5.23^{\circ} \mathrm{E}\right.$ and $13.07^{\circ} \mathrm{N}$ ) in the northern part of the country. The seasonality is consistent with results in literature and the implication of the results for hydrological and allied models has been trumpeted since evapotranspiration in addition to soil moisture are state variables used as initial boundary conditions that influence many hydrological, weather and climate related processes. The study concludes that food shortages arising from climate change and a fast changing landscape due to unsustainable management of the ecosystem could be minimized if the hydrological processes is properly quantified and applied.
\end{abstract}

Keywords: Evapotranspiration, Agro-climatology, Food security, Climate change, Water balance

\section{INTRODUCTION}

Evaporation is the loss of water from open bodies of water, such as lakes and reservoirs, wetlands, bare soil, and snow cover while transpiration is the loss from living-plant surfaces. Several factors other than the physical characteristics of the water, soil, snow, and plant surface also affect the evapotranspiration process. In a broad definition, the evapotranspiration is a combined process of both evaporation from soil and plant surfaces and transpiration through plant canopies. In the evapotranspiration process, the water is transferred from the soil and plant surfaces into the atmosphere in the form of water vapor. In practice (Allen et al., 1998), the estimation of the evapotranspiration rate for a specific crop requires first calculating potential or reference evapotranspiration and then applying the proper crop coefficients $\left(\mathrm{K}_{\mathrm{c}}\right)$ to estimate actual crop evapotranspiration $\left(\mathrm{ET}_{\mathrm{a}}\right)$.
The more important factors include net solar radiation, surface area of open bodies of water, wind speed, density and type of vegetative cover, availability of soil moisture, root depth, reflective land-surface characteristics, and season of year. It is agreed among the science community that the Earth's climate will undergo changes in response to natural variability, including solar variability, and to increasing concentrations of greenhouse gases and aerosols (Ayoade, 1988). These changes may profoundly affect atmospheric water vapour concentrations, clouds, and precipitation patterns. The IPCC (2007) Fourth Assessment Report projected warmer and more frequent hot days and nights, warm spells/heat waves in most land areas in the region, with a possibility of very high rates of evapotranspiration which may accelerate the hydrologic cycle, resulting in an increase in the amount of moisture circulating through the atmosphere (Ayoade, 1988). The question now and for the future is determining how much evapotranspiration (ET) actually occurs or would occur especially with the uncertainties associated with 
projection of precipitation in the region? Computation with a numerical model of the atmosphere also showed that the global fields of rainfall, temperature, and motion strongly depend on the land-surface evapotranspiration, which validates the long-held idea that surface vegetation, which produces the evapotranspiration, is an important factor in the earth's climate (Adefolalu, 1988). ET is a difficult parameter to measure, but various methods have been developed to try to get at that upward flux of moisture (Giorgi et al., 1993; Jianbiao et al., 2005; Xu and Chen, 2005; Ali et al., 2008; Jain et al., 2008). Human alteration of the Earth's land cover is escalating. This change can significantly impact evapotranspiration in regional ecosystems, which in turn influences the global hydrological cycle (Cotton and Pielke, 2007; Li et al., 2007). The magnitude of this influence is unknown as accurate estimates of the human impact on terrestrial evapotranspiration are lacking (Begon et al., 1990). However, six spheres of human activity in Africa are known to affect the evapotranspiration vis-à-vis the hydrological process. These includes (i) conversion of forests into agriculture, (ii) conversion of forested land to urban areas, (iii) conversion of land to grazing, (iv) deforestation and tree farms, ( $v$ ) creation of water reservoir, and (vi) burning of biomass (Dickinson et al., 1986; Adefolalu, 1988; Clark, 2004; Avissar and Werth 2005) . In addition, the reflective characteristics of the land surface also have an effect on the magnitude of evapotranspiration. This is where rapid urbanization due to population increase in Africa and especially the sub-Saharan countries comes into focus.

Tropical forests are disappearing or deteriorating, due especially to population pressures and nonsustainable resource utilization. The chief concerns surrounding tropical deforestation are the consequent impacts on species diversity, atmospheric chemistry, and land surface-atmosphere interaction (Fohrer et al., 2005; Fasona and Omojola, 2005) which is an important component of climate system, posing greater challenge in developing or improving the landsurface scheme of GCMs and Regional Climate Models (RCMs). Tropical forests also play an important role in the hydrological cycle (Gash and Nobre, 1997; Sellers et al., 2002). Water is lost from trees to the atmosphere through interception loss (evaporation of the part of the rainfall that remains on leaves) and through normal plant transpiration.

Climate change as a global phenomenon affects ET and poses economic, social, and ecological obstacles to the global community. In particular, smallholder farming communities in low-income countries such as Nigeria will be adversely affected by climate change because of the increased erratic rainfall regimes, increased frequency and intensity of extreme weather events, and general unpredictability of agricultural operations, which are the fallouts that have been predicted to be associated with the phenomenon. Given the increasing human population and the attendant requirements of food and fibre, efforts to increase food production in Nigeria will depend on the improved management of water resources nationwide including, rigorous quantitative estimation of the major components of water balance (Adefolalu, 1988). In this study, we analyzed the evapotranspiration levels for the 36 state capitals and the capital city of Nigeria (Abuja). We have alluded how the ET datasets will help policy makers and resource managers in Nigeria, south of the Sahara in West Africa to make informed decisions on planning and policies related to water resources development. We also highlighted how the study could be of benefit to the critical mass of atmospheric scientists and hydrologists in Nigeria in particular and the Sub-Saharan Africa through enhanced knowledge in the understanding, quantifying and incorporating the hydrological processes. This is from the viewpoint of meeting the Millennium Development Goals (MDG) of alleviating poverty, hunger and maintaining a sustainable environment in the face of an increasing evidence of biological and ecological cost of climate change.

\section{METHODS}

Geography of the study area: Nigeria is located in the tropical zone of West Africa between latitudes $4^{\circ}$ $\mathrm{N}$ to $14^{\circ} \mathrm{N}$ and longitudes $2^{\circ} 2^{\prime} \mathrm{E}$ to $14^{\circ} 30^{\prime} \mathrm{E}$. It has a total area of $923770 \mathrm{~km}^{2}$. The 36 state capitals and their coordinates are listed in Fig 1 which is representative of the agro ecological zones of the country. Nigeria's north-south extent is about $1050 \mathrm{~km}$ and its maximum east-west extent is about $1150 \mathrm{~km}$. It is bordered to the west by Benin, to the northwest and north by Niger, to the northeast by Chad and to the east by Cameroon, while the Atlantic Ocean forms the southern limits of the country's territory (Fig. 1). Nigeria is indeed a unique tropical country that cuts across all tropical ecological zones. From the Atlantic Ocean down to the edge of the Sahara, all tropical ecological zones are found. These include: the southern zone of Mangrove swamp located between latitude $4^{\circ}$ and $6^{\circ} 30^{\prime} \mathrm{N}$, the Tropical rainforest found around latitude $6^{\circ} 30^{\prime}$ to $7^{\circ} 45^{\prime}$ stretching from the southwest to the southeast, the Guinea Savannah belt around latitude $7^{\circ} 45^{\prime} \mathrm{N}$ to $10 \mathrm{~N}$, the Sudan Savannah belt around $10^{\circ} \mathrm{N}$ to $12^{\circ} \mathrm{N}$ and the Sahel Savannah in areas above latitude $12{ }^{\circ} \mathrm{N}$ (Adefolalu, 1988; Fasona and Omojola, 2005). 
Am. J. Sci. Ind. Res., 2011, 2(2): 191-204

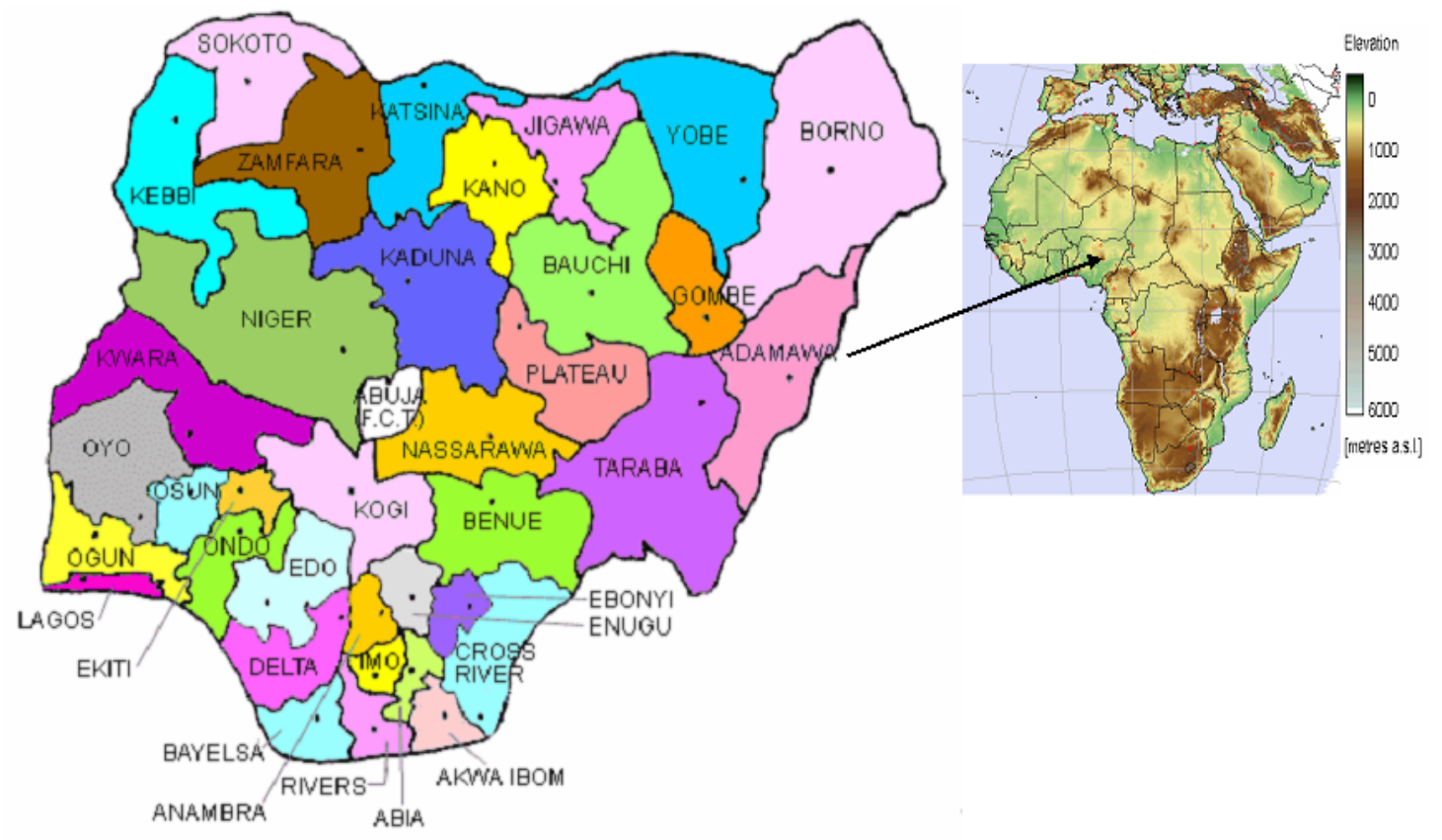

Fig. 1. Map of the 36 states of Nigeria within Africa

The climate of Nigeria is dominated by the seasonal movement of the West African Monsoon driven by the differential changes in sea surface temperature (SSTs) of the Atlantic (north and south) and the Indian Ocean (Brooks, 2004) with possible contribution from changes in land surface, vegetation dynamics, moisture flux and possibly dust via secondary feedback mechanisms. Rainfall averages over $2000 \mathrm{~mm}$ per annum in the humid southeast, $1000 \mathrm{~mm}$ in the centre reducing to as low as $500 \mathrm{~mm}$ in the north east with a steep north south rainfall gradient with roughly parallel latitudinal isohyets. While the climate in the humid areas is relatively stable, variability increases as one moves north through the sub-humid and semi-arid zones. Similarly, the vegetation of thick mangrove forests and dense rain forests in the south gives way to a near-desert condition in the North-eastern corner of the country. According to the Nigerian National Committee on Irrigation and Drainage (NINCID), the county is divided into eight agro-ecological zones for the purpose of irrigation practices based on rainfall and temperature which are the most significant parameters (http://www.icid.org/cp_nigeria.html). Nigeria is listed by FAO among those nations that are at the moment technically unable to meet their food needs from rain-fed production at a low level of inputs and appear likely to remain so even at intermediate levels of inputs at some point in time between 2000 and 2025.
Meta data: Long term monthly evapotranspiration data for the period 1961-1990 for the locations shown in Fig. 1 and whose coordinates are listed in Table 1 were obtained from the Integrated Database Information System (IDIS), an OPEN ACCESS, online data sharing platform developed by the International Water Management Institute (IWMI) for all stakeholders and particularly to give irrigation and agricultural planners rapid access to accurate data on climate and moisture availability for agriculture. It presents the evapotranspiration rates in $\mathrm{mm}$ per day.

The station data used in the dataset have been collated at the Climatic Research Unit during research carried out over many years funded by (among others) the UK Natural Environment Research Council, the UK Department of Environment Transport and Regions and the US Department of Energy. Further details about the data are presented elsewhere: http://dw.iwmi.org/IDIS_DP/clickandplot.aspx. The site provides access to world coverage of climate and hydrology average and time series data. Each indicator/dataset can either be downloaded, plotted or reviewed in a metadata format in two ways; i) to select a location through the map (ii) to select a location through its coordinates (longitude and latitude in decimals of degree). 
Table 1: The 36 states of Nigeria and their coordinates

\begin{tabular}{|c|c|c|c|}
\hline State & Capital & $\begin{array}{c}\text { Longitude } \\
\text { (degrees East) }\end{array}$ & Latitude (degrees North) \\
\hline \multicolumn{4}{|l|}{ South South zone } \\
\hline Akwa-lbom & Uyo & 7.93 & 5.05 \\
\hline Bayelsa & Yenegoa & 6.26 & 4.92 \\
\hline Cross River & Calabar & 8.32 & 4.95 \\
\hline Delta & Asaba & 6.18 & 6.75 \\
\hline Edo & Benin & 5.60 & 6.32 \\
\hline Rivers & Port-Harcourt & 7.00 & 4.75 \\
\hline \multicolumn{4}{|l|}{ South East zone } \\
\hline Abia & Umuahia & 7.48 & 5.53 \\
\hline Anambra & Awka & 7.73 & 6.20 \\
\hline Ebonyi & Abakaliki & 8.10 & 6.33 \\
\hline Enugu & Enugu & 7.50 & 6.50 \\
\hline Imo & Owerri & 7.02 & 5.48 \\
\hline \multicolumn{4}{|l|}{ South West zone } \\
\hline Ekiti & Ado Ekiti & 5.22 & 7.62 \\
\hline Lagos & Ikeja & 3.33 & 6.58 \\
\hline Ogun & Abeokuta & 3.33 & 7.15 \\
\hline Ondo & Akure & 5.20 & 7.25 \\
\hline Osun & Osogbo & 4.57 & 7.77 \\
\hline Oyo & Ibadan & 3.90 & 7.38 \\
\hline \multicolumn{4}{|l|}{ North Central zone } \\
\hline Benue & Makurdi & 8.53 & 7.73 \\
\hline Kogi & Lokoja & 6.82 & 7.75 \\
\hline Kwara & Ilorin & 4.55 & 8.50 \\
\hline Nasarawa & Lafia & 8.52 & 8.48 \\
\hline Niger & Minna & 6.55 & 9.62 \\
\hline Plateau & Jos & 8.90 & 9.92 \\
\hline Abuja & Abuja & 10.00 & 9.00 \\
\hline \multicolumn{4}{|l|}{ North East zone } \\
\hline Adamawa & Yola & 11.93 & 9.91 \\
\hline Bauchi & Bauchi & 9.83 & 10.32 \\
\hline Borno & Maiduguri & 13.15 & 11.83 \\
\hline Gombe & Gombe & 11.17 & 10.28 \\
\hline Taraba & Jalingo & 11.37 & 8.90 \\
\hline Yobe & Damaturu & 11.95 & 11.73 \\
\hline
\end{tabular}


Am. J. Sci. Ind. Res., 2011, 2(2): 191-204

\begin{tabular}{|l|l|c|c|}
\hline \multicolumn{1}{|c|}{ State } & \multicolumn{1}{|c|}{ Capital } & \multicolumn{1}{c|}{$\begin{array}{c}\text { Longitude } \\
\text { (degrees East) }\end{array}$} & 10.52 \\
\hline Kaduna & Kaduna & 7.43 & 11.50 \\
\hline Kano & Kano & 8.50 & 12.98 \\
\hline Katsina & Katsina & 7.60 & 12.45 \\
\hline Kebbi & Birni kebbi & 4.20 & 11.73 \\
\hline Jigawa & Dutse & 9.28 & 13.07 \\
\hline Sokoto & Sokoto & 5.23 & 12.17 \\
\hline Zamfara & Gusau & 6.67 & \\
\hline
\end{tabular}

\section{RESULTS}

Evapotranspiration levels in Nigeria: Though evapotranspiration exhibits similar rends across all regions- with high rates between February and March and lowest rates between July and September-, there is wide variation within the geopolitical zones and between seasons in response to prevailing weather conditions. Estimates of average for wet and dry season nationwide evapotranspiration ranged from $3.74 \mathrm{~mm}$ in the South and $5.81 \mathrm{~mm}$ in the Northern zones. Results in the North showed that during the dry season, evapotranspiration rate is magnified, because evapotranspiration continues to deplete the limited water supplies in addition to increased solar energy. The monthly mean evapotranspiration (mm/day) for the six state capitals in the oil-rich South-south geopolitical zone of Nigeria is shown in Figure 2.

The ET seasonality is well accounted for by the dataset obtained from the International Water and Management Institute (IWMI). Port-Harcourt $\left(7^{\circ} \mathrm{E}\right.$ and $4.75^{\circ} \mathrm{N}$ ) which is in the vicinity of the Atlantic ocean have the least amount of evapotranspiration that ranged from $2.68 \mathrm{~mm}$ in July to $3.81 \mathrm{~mm}$ in February. In this riverine state, land and water are treasured highly, but because of oil exploration and exploitation activities (onshore) the land-surface and ecology is being degraded. The extensive degradation contributes to general restiveness in the region with a spiral effect on world crude oil prices. Mismanagement of the hydrological process has negative effects on world economy as highlighted by the several FAO studies on links between hydrology, agriculture, food security and poverty (Chineke, et al., 2008; Rockström et al., 2008). Although the level of evapotranspiration is low, the farmlands are degraded as a result of pollution from oil exploitation activities. This further aggravates socio-political tension among the population in the region because crop yield is decreasing and fishing, another important economic sub-sector that supplies fish for nourishment and improved household income is, severely impacted by pollution.

In Figure 2, the more inland Asaba $\left(6.18{ }^{\circ} \mathrm{E}\right.$ and 6.75 ${ }^{\circ} \mathrm{N}$ ), a city on the bank of River Niger is gradually "drying out", due to climate change and had more evapotranspiration levels for all the months compared to the other sites in the South-south geopolitical zone of Nigeria. With such high quality and free datasets available from IWMI, the hydrology of Asaba and adjourning towns like Onitsha can be studied in detail. Literature on rainfall, runoff and stream flow in addition to biogeochemical hydrology of River Niger is almost absent for this watershed. Figure 3 shows the monthly mean evapotranspiration ( $\mathrm{mm} /$ day) for the sites in the southeast geopolitical zone of Nigeria. The ET levels show the seasonality expected $[4,22$, 24] since the peak dry season months of February and March had the greatest amounts of evapotranspiration (Fig. 3) while the peak rainfall months of June, July and August (JJA) had low ET values. Owerri $\left(7.02^{\circ} \mathrm{E}\right.$ and $\left.5.48^{\circ} \mathrm{N}\right)$, which is the site closest to the coast of others in the zone, recorded the least amount of evapotranspiration. Enugu (7.50 ${ }^{\circ} \mathrm{E}$ and $6.5^{\circ} \mathrm{N}$ ), Awka $\left(7.73^{\circ} \mathrm{E}\right.$ and $6.20^{\circ} \mathrm{N}$ ) and Abakaliki $\left(8.1^{\circ} \mathrm{E}\right.$ and $\left.6.33^{\circ} \mathrm{N}\right)$ had more levels of ET during the period 1961-1990. One point worth mentioning is that agriculture in this densely populated zone is rainfed, with the land-cover and surface albedo changing as a result of unsustainable food production systems, deforestation and climate change evidenced by increasing rainfall variability (UNEP, 2007; Odekunle and Eludoyin, 2008; Salako, 2008). 


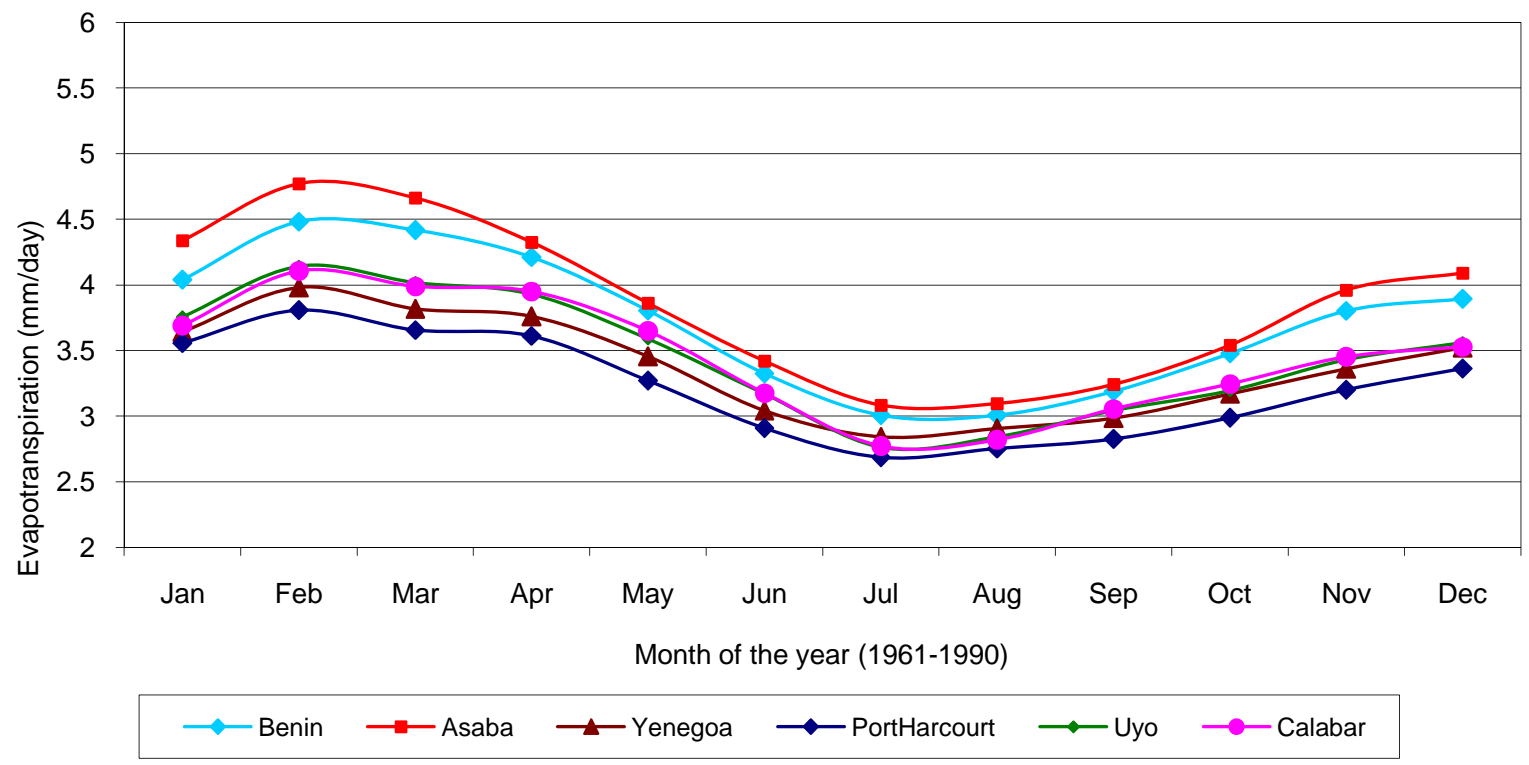

Fig 2: Monthly mean evapotranspiration levels (mm/day) for the South-south geopolitical zone of Nigeria

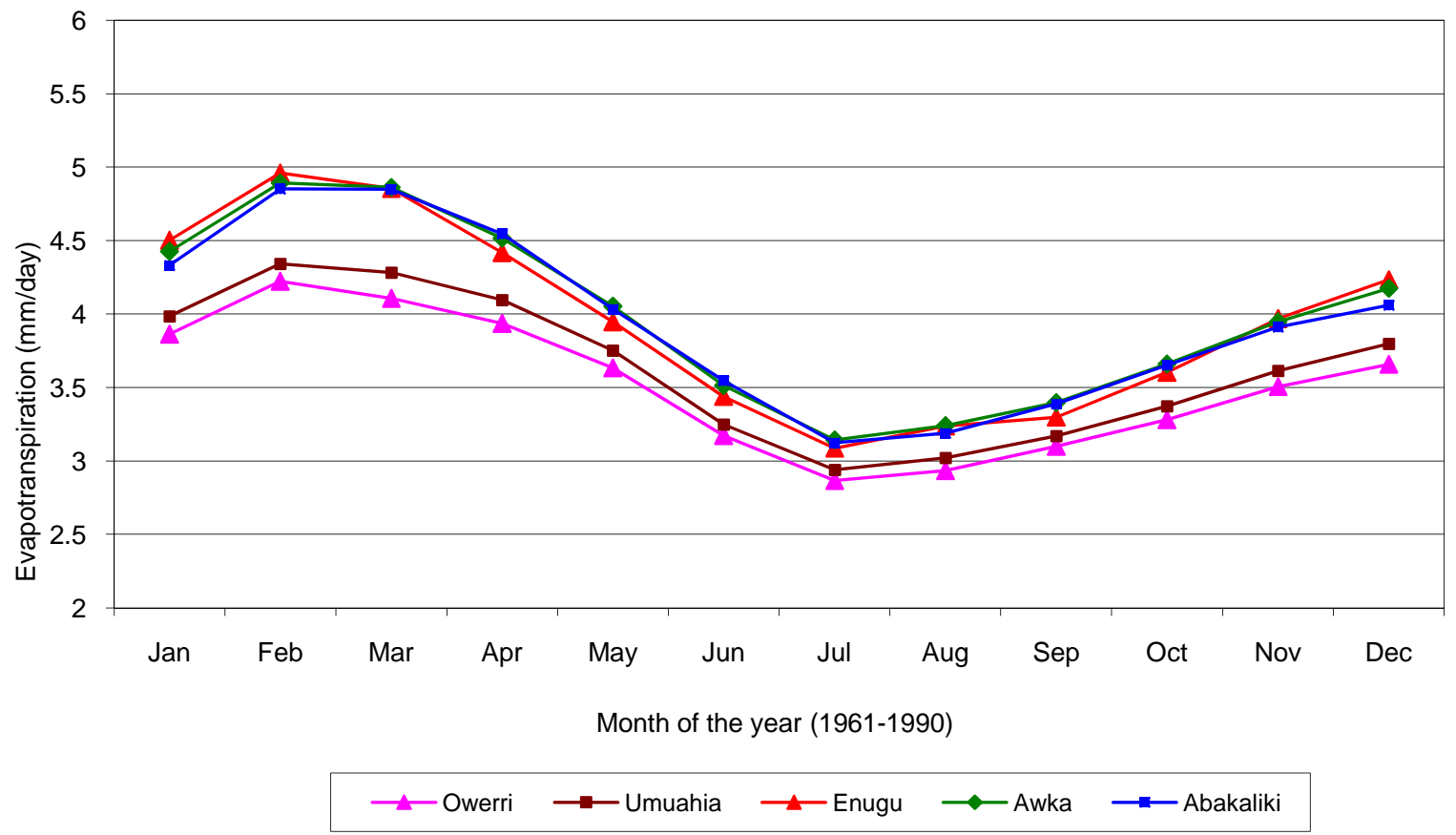

Fig 3: Monthly mean evapotranspiration levels ( $\mathrm{mm} /$ day) for the Southeast geopolitical zone of Nigeria 
Am. J. Sci. Ind. Res., 2011, 2(2): 191-204

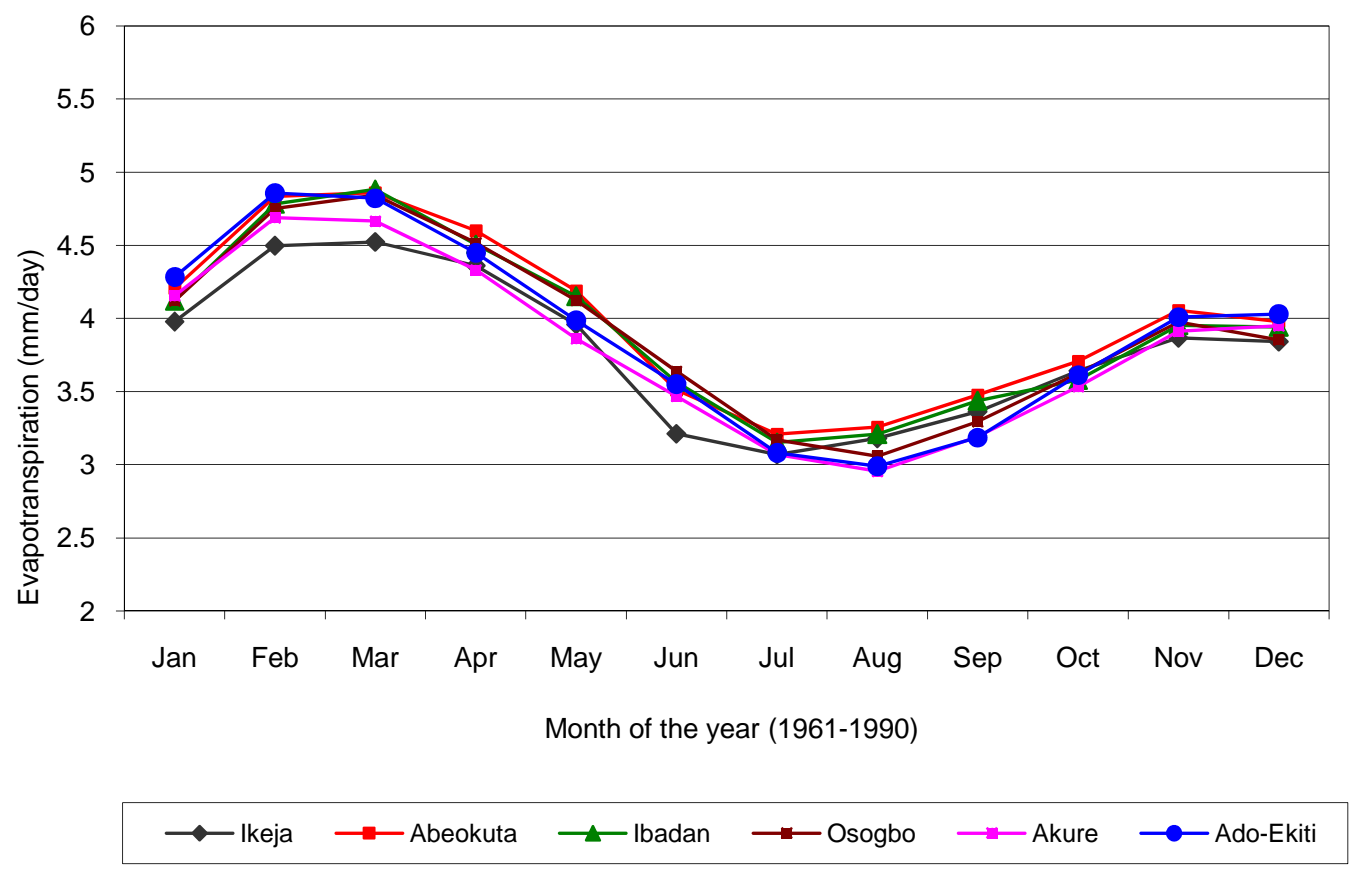

Fig 4: Monthly mean evapotranspiration levels ( $\mathrm{mm} / \mathrm{day})$ for the Southwest geopolitical zone of Nigeria

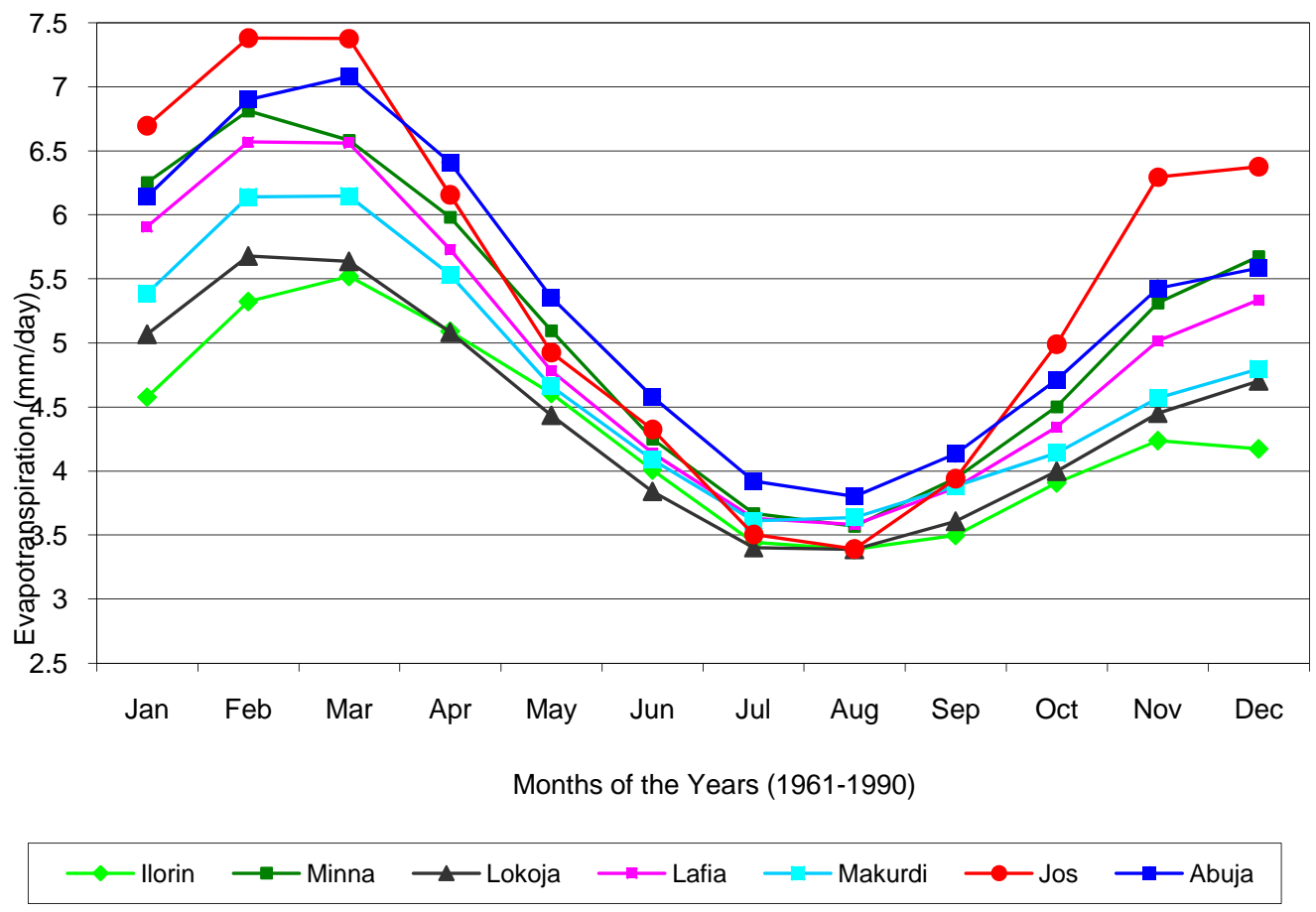

Fig 5: Monthly mean evapotranspiration levels ( $\mathrm{mm} /$ day) for the Northcentral geopolitical zone of Nigeria 
For the southwest geopolitical zone of Nigeria (Fig. 4), Ikeja site $\left(3.33^{\circ} \mathrm{E}\right.$ and $\left.6.58{ }^{\circ} \mathrm{N}\right)$ located close to the Atlantic ocean had ET values that ranged from $3.08 \mathrm{~mm}$ in the month of July to $4.50 \mathrm{~mm}$ in February which were generally lower than those of the more inland sites of Abeokuta, Ibadan, Osogbo, Akure and Ado Ekiti. Agriculture in this part of the country is not sustainable since it is rainfed and the rainfall patterns over the years are changing (Odekunle and Eludoyin, 2008). The land-cover is also changing due to urbanization, poor land use planning and land tenure programmes. The ET information helps in understanding farm water and soil management for improved water use or introduction of non-native vegetation in the areas. Though, for years, the International Institute of Tropical Agriculture (IITA), Ibadan, Nigeria has been championing efforts at minimum tillage that will help the land-surface optimize evapotranspiration with its deliverables as improved crop yield and poverty reduction, but much still remains to be accomplished as the field level adoption of the tillage technique by the majority of smallholder farm households is low.

The North central geopolitical zone of Nigeria is popularly called the "food basket" of the nation since most of the food production in the country takes place in the zone. The ET seasonality expected for a tropical location [3] is well represented by the IWMI dataset for this zone (Fig. 5). The site llorin $\left(4.55^{\circ} \mathrm{E}\right.$ and $8.50{ }^{\circ} \mathrm{N}$ ) and Lokoja $\left(6.82{ }^{\circ} \mathrm{E}\right.$ and $\left.7.75^{\circ} \mathrm{N}\right)$, a confluence town for Rivers Niger and Benue have the least amounts of ET ( $\mathrm{mm} /$ day) compared to the other sites in the zone (Fig. 5). The land-cover is treasured in this part of the country and the ET datasets can help in studying the ecology of the surrounding rivers that are gradually "drying out". Commercial farmers in the zone make use of irrigation which calls for a robust, transparent and well-coordinated use of the water resources that are not immuned to climate change. Given the strategic importance of the North central zone as the major "food basket" of the nation and as the seat of government political and administrative centre (Abuja), hydrological processes that affect the North central zone can have a triggering effect on the economy of both the rural peasant and minority large-scale farmers. The close linkage between land-surface and hydrology and its potential effect to fuel socio-political crises has been reported in Darfur, Sudan (UNEP, 2007).

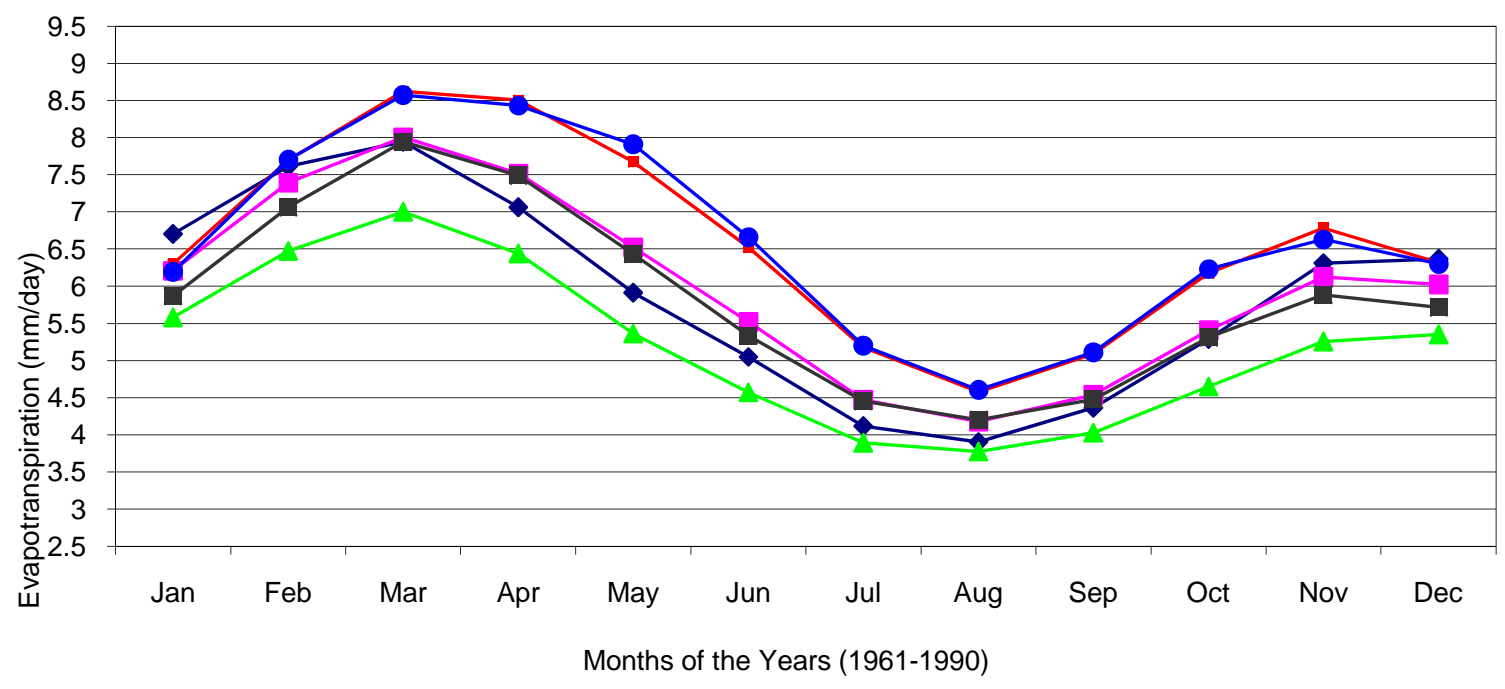

$\multimap$ Bauchi $\longrightarrow$ Gombe $\longrightarrow$ Jalingo $\rightarrow$-Yola $\longrightarrow$ Damaturu $\longrightarrow$ Maiduguri

Fig 6: Monthly mean evapotranspiration levels (mm/day) for the Northeast geopolitical zone of Nigeria 
Am. J. Sci. Ind. Res., 2011, 2(2): 191-204

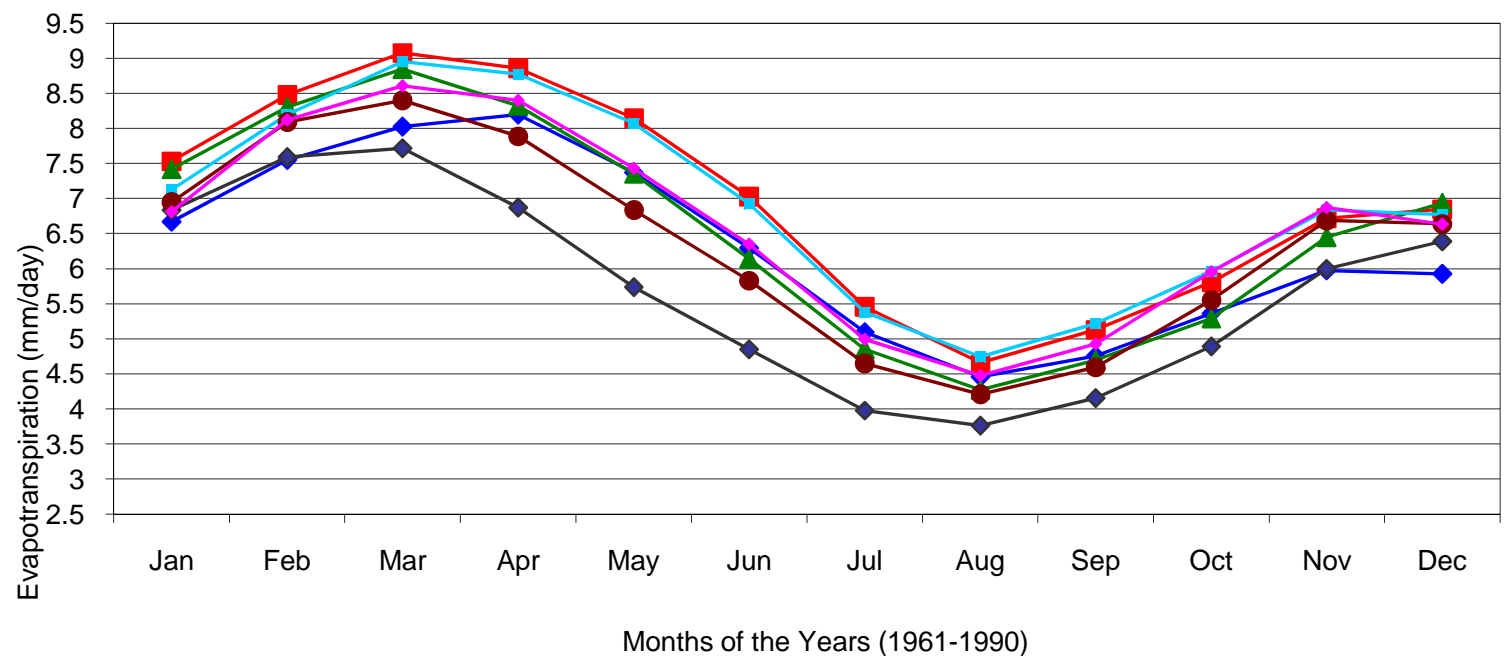

$\multimap$ Birni Kebbi $\longrightarrow$ Sokoto $\longrightarrow$ Gusau $\multimap$ Kaduna $\longrightarrow$ Katsina $\longrightarrow$ Kano $\longrightarrow$ Dutse

Fig 7: Monthly mean evapotranspiration levels ( $\mathrm{mm} / \mathrm{day})$ for the Northwest geopolitical zone of Nigeria

In the North-eastern part of Nigeria, Jalingo $\left(11.37^{\circ} \mathrm{E}\right.$ and $8.90^{\circ} \mathrm{N}$ ) has the lowest ET level compared to the other sites (Fig. 6). This zone depends mainly on rainfed agriculture although there are limited irrigation facilities which few large-scale farmers use for irrigated farming. Unrestricted cattle grazing, which is common in the northern parts of Nigeria takes a toll on the land-cover and water sources. This competition for water and fodder resources often results in frequent conflicts between livestock herders and farmers. Similar conflict for resource control between pastoral and crop farmers have been reported in southern Africa [Ajayi and Kwesiga, 2003; Ajayi and Katanga, 2006). The ET results for Jalingo ranged from $3.77 \mathrm{~mm}$ in August to $7 \mathrm{~mm}$ in the dry season month of March when farmers start planning for the next planting season and biomass burning, an enemy of a sustainable "landscape" and ecology is prevalent (Fig. 6). Bush fires which are carried out by poachers who hunt for animals, (locally called "bush meat") are also commonplace. This may be reduced if there are functional and effective forest policies in place. Droughts are common in the northern part of the country and when water is insufficient, supplementary water through irrigation to supply water required to produce a crop that is consumed by transpiration from the stomata of leaves or from the soil or between the plants (Ayoade, 1988). Mechanized irrigated farming should not be an "all- comer's affair", rather water conservation efforts (Clemmens and Allen, 2005) need to be geared up in the North-eastern part of the country towards improving the infrastructure of the irrigation system so that water can be controlled more easily and the right amount of water applied at the right time. It needs to be pointed out that access to portable water, which is consistent with the Millennium Development Goals (MDG) is still a luxury for more than 70 percent of the residents of this geopolitical zone of Nigeria.

For the more arid and drought-prone Northwest geopolitical zone, the monthly mean ET (mm/day) in Figure 7 is similar to the expected seasonality obtained for other geopolitical zones of Nigeria (Figures 2-6). The values for Kaduna $\left(7.43^{\circ} \mathrm{E}\right.$ and $10.52^{\circ} \mathrm{N}$ ) located within the Kaduna River basin were lower than those of other sites (Birni-Kebbi, Sokoto, Gusau, Katsina, Kano and Dutse). The IWMI dataset reproduced the seasonal patterns expected with the lowest value of ET being $3.76 \mathrm{~mm}$ for the month of August in Kaduna and $9.08 \mathrm{~mm}$ for the month of March at Sokoto $\left(5.23^{\circ} \mathrm{E}\right.$ and $\left.13.07{ }^{\circ} \mathrm{N}\right)$. There is the need to critically evaluate the consumptive use of water by the crops grown in this part of the country like maize, sorghum, millet and guinea corn. Since food production in the zone is also rainfed although more productive when irrigated, the ET datasets will 
help to quantify irrigation efficiency and uniformity (Clemmens and Allen, 2005).

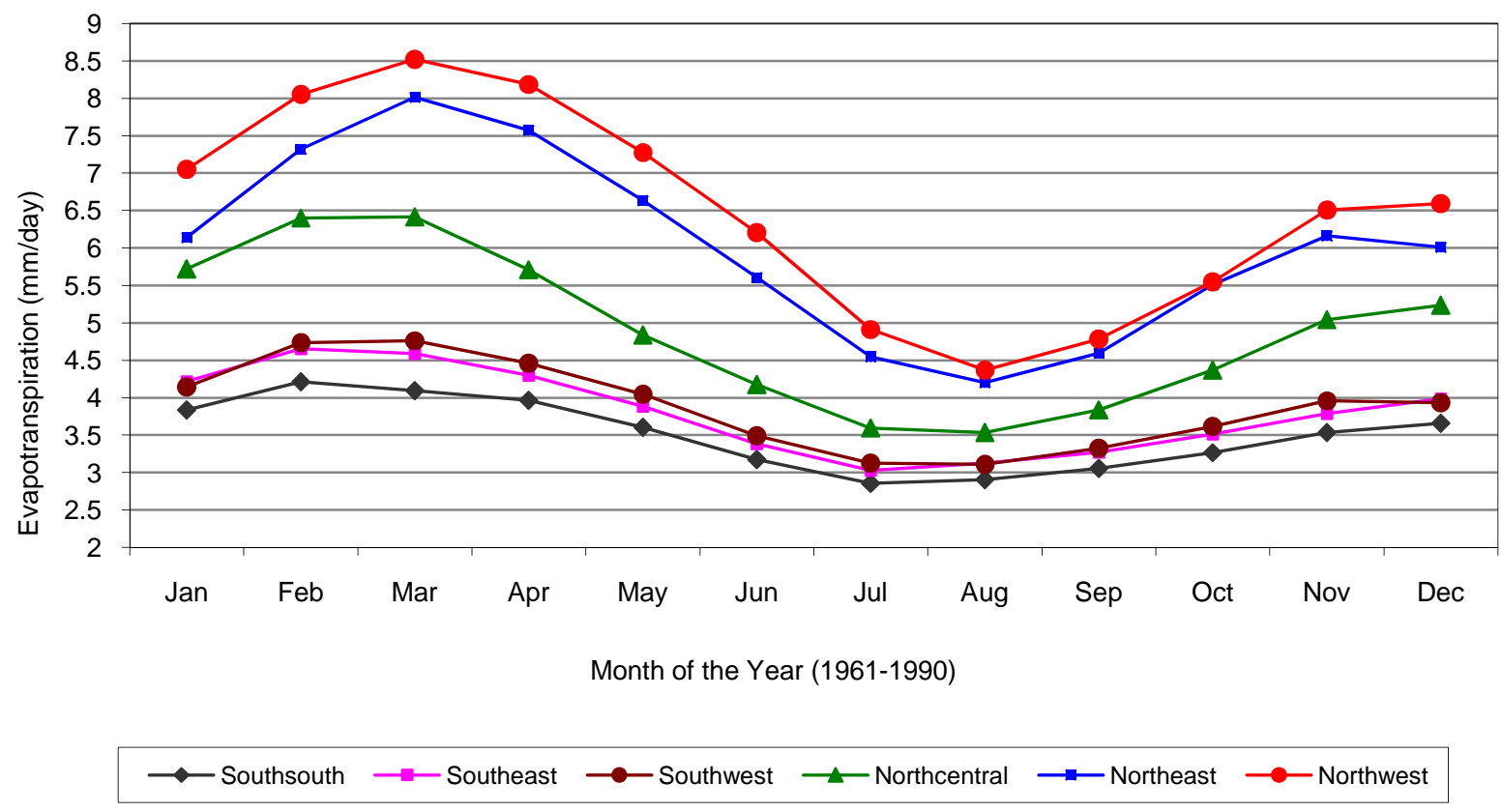

Fig 8: Regional mean evapotranspiration levels ( $\mathrm{mm} / \mathrm{day})$ for all the geopolitical zones

Discussion of results and implications: Land is a critical productive asset, and many livelihoods depend on this asset, in sub-Saharan Africa (Sanchez, 2002; Vanlauwe and Giller, 2006; Challinor et al., 2007). For many dry lands populations in the Sahel region of Africa, land degradation is a major factor that affects their ability to achieve food security and improve their standard of living (Ayoade, 1988). Because dry lands typically have low vegetation cover, they are particularly vulnerable to mismanagement that results in the removal of grasses, bushes and trees exist, exposing the thin layer of fertile topsoil to wind and water erosion (Adefolalu, 1988). Poorly-managed, intensified land use and deforestation of productive dry lands may result in land which cannot support agriculture, and sometimes not even pastoralism. Even far away from the Sahel like in the coastal parts of Nigeria, the land-surface is being degraded due to mismanagement and non-adherence to development plans and non-sustainable farming systems. If transparent land tenure reforms are adopted in the sub-region, the hydrological process with benefit in the short and long run.
The differences in results between South and North are due to differences in climatic conditions and land cover in the different location. Rainfall is generally heavier in the South but decreases northwards towards Kano and West wards in the direction of Sokoto. Harmattan dry winds blow for four to five months in the northern region as compared with two or three weeks in the coastal areas, this brings a considerable drop in relative humidity. Evapotranspiration depends on the amount of moisture available in the soil and precipitation. In the more coastal geopolitical zones of Nigeria, the insolation is lower than in the Northern geopolitical zones. During the dry season, the relative humidity is lower than in the Northern parts of the country. Even during the rainy season months of April to September when the relative humidity should be higher (Adefolalu, 1988; Jianbiao et al., 2004; Rockström et al., 2008), the clouds that normally reduce the amount of solar insolation has more impact in the more humid southern than the more arid northern sites.

In understanding climate change relationship with water resources, there may be the need for measured and tree-ring-reconstructed stream flow 
data and ice cores that will inform planners about climate-induced changes in the timing of runoff and the range of climate variability over centuries. Paleoclimate data is almost unavailable south of the Sahara. Nonetheless, with the evapotranspiration dataset from the International Water Research Institute (IWMI), an ecosystem investigation that tends to understand how plants respond to changes in atmospheric carbon dioxide and how such changes might affect land-use cover and, in turn, the hydrologic system is made possible. Application of improved evapotranspiration estimations in a calibrated hydrological model will demonstrate the added value of earth observation products for the study of the hydrological cycle. Hydrological processes that determine the exchange of water and energy at the earth's surface, the movement of water in soils, and the processes and pathways linking precipitation to stream flow determine catchment water balances and rainfall-runoff relationships, and hence water resource availability, flood generation and the feedbacks between the earth's surface and the global climate.

The IWMI ET dataset helps agro-meteorologists, agronomists, irrigation engineers and development planners in Nigeria to carry out standard calculations for evapotranspiration and crop water use studies, and more specifically the design and management of irrigation schemes. One output will be the development of recommendations for improved irrigation practices, the planning of irrigation schedules under varying water supply conditions, and the assessment of production under rainfed conditions or deficit irrigation. Nevertheless, since calculations of crop water requirements and irrigation requirements are carried out with inputs of climatic and crop data, high -quality crop and climate data, preferably, in daily series will be needed from across the Nigerian environments and other parts of Africa to complement the efforts of the International Water Research Institute (IWMI) and the Food and Agricultural Organization (FAO) efforts at helping to further the mandate of the United Nations (UN) through the Millennium Development Goals (MDG) of reducing hunger. Food is not negotiable item because Sub-Saharan Africa is the only region in the world where per capita food has been decreasing in the past decade. As the population of Africa increases and the continent continues to face the challenge to attain food security for increasing human population and conserve natural resource base, efforts need to be geared towards providing food for all and practically implementing low cost water and soil conservation technologies like water harvesting and soil tillage and mulching (Clemmens and Allen, 2005).

\section{CONCLUSION AND RECOMMENDATIONS:}

The world and, in particular, developing countries and the poor have been hit by both food and energy crises (Challinor et al., 2007). As a consequence, prices for many staple foods have risen by up to $100 \%$ in some cases and particularly in African countries plagued by wars (like Somalia, Sudan) or political instability like Zimbabwe. Thus we have a classic increase in prices due to high demand and low supply (Chartres, 2008). As water scarcity is one of the most pressing issues facing humanity today and provision of sufficient water is necessary for human health and poverty reduction, climate change may also add to existing conflicts. A good example is the United Nations Environment Programme (UNEP) report, which suggested that the conflict in Darfur, Sudan particularly between herders and farmers is in part driven by climate change and environmental degradation (UNEP, 2007). Over the past 40 years, rainfall in the region has decreased by 30 per cent and the Sahara has advanced by more than a mile every year. The UNEP report warned of a succession of new wars across Africa unless more is done to contain the damage of climate change, concluding that "Darfur holds grim lessons for other countries at risk." The restiveness in the Niger Delta region of Nigeria, with the spiralling effect on crude oil exploration and exploitation, is also related to management of the environment vis-à-vis the landscape and water resources.

This study analyzed datasets to determine the level of ET in the different geo-political zones of Nigeria with a view to enhancing knowledge in the understanding, quantifying and incorporating of hydrological processes. This is done with the aim to providing policy makers and resource managers with information that assist them to make informed decisions on planning and policies related to water resources development. Such information is important given the global phenomenon of climate change which imposes economic, social, and ecological challenges on the global community and, to smallholder farmers in particular. Based on the results presented in this study, a number of inferences, conclusions and recommendations for policies can be made. First, Nigeria may have to adopt simple policies like returning croplands to forests which will boost evapotranspiration levels all over the country. Risk assessment of future land use 
changes with respect to their ecological impact is still an unsolved problem (Fohrer et al., 2005). The implementation of sustainable land use concepts for the Nigerian environment will require a methodology that is able to quantify the effects on the hydrological processes the ecosystem. Due to population explosion, urban areas are increasing with the natural (permeable) surfaces being replaced by impermeable (man-made) surfaces thereby reducing infiltration and increasing the phenomenon of flooding which is now prevalent across parts of the Nigerian urban areas. The farms for food production are located away from the urban areas and since precipitation replaces the moisture removed by evapotranspiration from the soil, a regular monitoring of these hydrological processes will yield a means of estimating the amount of water retained in the soil.

The monthly means of the evapotranspiration for the various geopolitical zones of Nigeria is shown in Figure 8. The southern more humid sites have ET values lower than the more arid northern zones with the Northwest geopolitical zone that has higher temperatures and solar radiation having higher values. We had stated earlier that there is an increasing evidence of rainfall variability that is impacting negatively agricultural production in this predominantly agrarian part of the country. We had mentioned that the landscape across Nigeria is changing due to increasing population, development, harvesting of biomass without concrete reforestation policies and efforts. We therefore finally present the ET levels during the "critical hydrological seasons" of March, April, May and June for the country (Table 2) when the farmers start clearing the "landscape" and burning them in readiness for the planting season. This is also the time for actual tillage and late planting activities. The Northern geopolitical zones from this report have higher evapotranspiration rates ( $\mathrm{mm} /$ day) underscoring the need to properly quantify every aspect of the hydrological process in Nigeria.

Table 2: Monthly mean evapotranspiration ( $\mathrm{mm} / \mathrm{day})$ in the various geopolitical zones of Nigeria during the peak of landscape activity (March - June)

\begin{tabular}{|c|c|c|c|c|c|c|}
\hline Month & Southsouth & Southeast & Southwest & Northcentral & Northeast & Northwest \\
\hline Mar & 4.093028 & 4.590944 & 4.765452 & 6.415423 & 8.013667 & 8.519634 \\
\hline Apr & 3.964972 & 4.302356 & 4.45993 & 5.712299 & 7.573797 & 8.18881 \\
\hline May & 3.604432 & 3.882998 & 4.045375 & 4.837153 & 6.634395 & 7.279819 \\
\hline Jun & 3.172483 & 3.383942 & 3.490783 & 4.175786 & 5.607422 & 6.204991 \\
\hline Mean & 3.708729 & 4.04006 & 4.190385 & 5.285165 & 6.95732 & 7.548314 \\
\hline
\end{tabular}

Secondly, the study of ET will be most beneficial in the southern parts of the country where flooding is becoming rampant and in the northern parts where irrigated agriculture needs to be used to boost food production to feed the increasing population as one of the ways of obviating climate change and meeting the United Nations Millennium Development Goals in addition to maintaining the rights of the most vulnerable sector of Nigeria's society; the physicallychallenged, women and children especially those that reside in the rural areas where more than 70 percent of Nigerians live.

\section{ACKNOWLEDGEMENTS:}

The authors are grateful to the Abdus Salam International Centre for Theoretical Physics (ICTP), Trieste, Italy for granting Associate Research Fellowship during which the principal author carried out this research. The Associate Scheme (http://assoc.ictp.it/) is one of ICTP's oldest Programmes, established to provide support for distinguished scientists in developing countries in an effort to lessen the brain-drain. The leave granted to the Principal author $\mathrm{Dr}$ Chineke by Imo State University, Owerri to conduct the study in ICTP is also gratefully acknowledged. The authors would like to greatly appreciate the assistance of Gamage, Nilantha of the International Water Management Institute (IWMI) for providing the links to access the dataset. Any errors or omissions contained herein are the authors' sole responsibility. 


\section{REFERENCES}

Adefolalu DO (1988). Precipitation trends evapotranspiration and the ecological zones of Nigeria. Theoretical \& Applied Climatology 39(2): 81-89.

Ajayi OC, Katanga R (2006). Faire respecter les pratiques agricoles traditionnelles. AGRIDAPE -Revue sur l'agriculture durable à faibles apports externes 21 : 1819.

Ajayi OC, Kwesiga F (2003). Implications of local policies and institutions on the adoption of improved fallows in eastern Zambia. Agroforestry systems 59 (3): 327336.

Ali S, Ghosh NC, Singh R (2008). Evaluating best evaporation estimate model for water surface evaporation in semi-arid region India. Hydrological Processes 22(8): 1093-1106.

Allen RG, Pereira LS, Raes D, Smith M (1998). Crop Evapotranspiration-Guidelines for Computing Crop Water Requirements. FAO Irrigation and drainage paper 56 Rome Italy: Food and Agriculture Organization of the United Nations Rome.

Avissar R, Werth D (2005). Global hydroclimatological teleconnections resulting from tropical deforestation. Journal of Hydrometeorology 6(2): 134-145.

Ayoade JO (1988). Tropical Hydrology and water resources, Macmillan Publishers: London pp 12-45.

Begon M, Harper JL, Townsend CR (1990). Ecology: individuals populations and communities 2nd ed, Blackwell Science Publishers Boston MA pp 2-12.

Brooks N (2004). Drought in the African Sahel: Long term perspectives and future prospects. Tyndall Centre Working Paper 61: 12-31.

Challinor A, Wheeler T, Garforth C, Craufurd P, Kassam A (2007). Assessing the vulnerability of food crop systems in Africa to climate change. Climatic Change 83: 381-399.

Chartres C (2008). Water: The Forgotten Crisis IWMI Feature Article by the IWMI Director General, June 2008.

Chineke TC, Okoro UK, Nwofor OK, Akwuegbu OP, Emelogu N, Chiemeka IU, Nwokocha CO (2008). Candidate equations for Potential Evapotranspiration: another step in humanizing the water research capacity in subtropical Africa. International Science Research Journal 1(2): 72-81.

Clark DA (2004). Tropical forests and global warming: slowing it down or speeding it up?. Frontiers in Ecology \& the Environment 2(2): 73-80.

Clemmens AJ, Allen RJ (2005). Impact of Agricultural Water Conservation on Water Availability Presentation at the 2005 EWRI World Water and Environmental Resource Congress Anchorage AK May 15-19 2005.

Cotton WR Pielke RA (2007). Human Impacts on Weather and Climate 2nd Edition Cambridge University Press London pp 12-39.

Dickinson RE, Henderson-Sellers A, Kennedy PJ, Wilson MF (1986). Biosphere -Atmosphere Transfer Scheme (BATS). for the NCAR Community Climate Model NCAR.

Fasona MJ, Omojola AS (2005). Climate Change Human Security and Communal Clashes in Nigeria Human Security and Climate Change An International Workshop Holmen Fjord Hotel Asker near Oslo 21-23 June 2005.

Fohrer N, Haverkamp S, Frede H-G (2005). Assessment of the effects of land use patterns on hydrologic landscape functions: development of sustainable land use concepts for low mountain range areas. Hydrological Processes 19(3): 659-672.

Gash JHC, Nobre CA (1997). Climatic effects of Amazonian deforestation: some results from ABRACOS. Bulletin of the American Meteorological Society 78: 823-830.

Giorgi F, Marinucci MR, Bates GT, De Canio G (1993). Development of a second generation regional climate model (RegCM2). I Boundary-layer and radiative transfer. Monthly Weather Review 121: 2794 - 2813.

Henderson-Sellers A, Yang Z-L, Dickinson RE (1993). The Project for Intercomparison of Land-surface Parameterization Schemes. Bulletin of American Meteorological Society, 74: 1335-1349.

IPCC (2007). Freshwater resources and their management Fourth Assessment Report Intergovernmental Panel on Climate Change.

Jain SK, Nayak PC, Sudheer KP (2008). Models for estimating evapotranspiration using artificial neural networks and their physical interpretation. Hydrological Processes 22(13): 2225 - 2234.

Jianbiao LU, Sun G, Mcnulty SG, Amatya DM (2005). A comparison of six potential evapotranspiration methods for regional use in the southeastern United States. Journal of the American Water Resources Association 41(3): $621-633$

Li L-J, Zhang L, Wang H, Wang J, Yang J-W, Jiang D-J, Li $J-Y$, Qin D-Y (2007). Assessing the impact of climate variability and human activities on stream flow from the Wuding River basin in China. Hydrological Processes 21(25): 3485-3491.

Odekunle TO, Eludoyin AO (2008). Sea surface temperature patterns in the Gulf of Guinea: their implications for the spatio-temporal variability of 
precipitation in West Africa. International Journal of Climatolology DOI: 101002/joc1656

Rockström J, Lannerstad M, Falkenmark M (2008). Assessing the water challenge of a new green revolution in developing countries. PNAS 104: 6253 6260.

Salako FK (2008). Rainfall variability and kinetic energy in southern Nigeria. Climatic Change 86(1-2): 151-164.

Sanchez PA (2002). Soil fertility and hunger in Africa. Science 295: 2019-2020.

Sellers P, Mintz Y, Sud A, Dalcher A (2002). A Simple Biosphere $(\mathrm{SiB})$ for use within General Circulation Models. Journal of Atmospheric Science 43: 505-531.

UNEP, 2007 Sudan: post-conflict environmental assessment United Nations Environnent Programme Nairobi.

Vanlauwe B, Giller KE (2006). Popular myths around soil fertility management in sub-Saharan Africa. Agricultural Ecosystem and Environment 116: 34-46.

Xu C-Y, Chen D (2005). Comparison of seven models for estimation of evapotranspiration and groundwater recharge using lysimeter measurement data in Germany. Hydrological Processes 19(18): 3717-3734. 